\title{
Fathers' Religious and Family Involvement at Home: Work and Family Outcomes
}

\author{
E.J. Hill", R.O. Whyte, J.I. Jacob, V.L. Blanchard, S.F. Duncan, D.C. Dollahite and L. Wadsworth \\ School of Family Life, Brigham Young University, Provo, Utah, USA
}

\begin{abstract}
This study investigates the impact of fathers' religious and family involvement on work-family conflict, workfamily fit, job satisfaction, and marital satisfaction. The sample consists of employed, married fathers and their spouses from the 2001 Marriott School of Management Alumni Work and Family Survey $(n=210)$. Fathers' family involvement was related to less work-life conflict, greater work-family fit, and greater self- and spouse-reports of marital satisfaction. Fathers' family and religious involvement was related to greater self- and spouse-reports of marital satisfaction. These findings suggest the importance of fathers' religious and family involvement to valued family and work outcomes.
\end{abstract}

\section{INTRODUCTION}

The influence of father involvement on the development of children and families has been well established [1]. Yet, working fathers are still relatively understudied, to the point of being "the forgotten half of working parents" [2]. In addition, despite evidence documenting the salience of religious involvement to family relationships [3] and acknowledgement of religion as relevant to father involvement [4] religion is rarely considered in family research.

The purpose of this study is to evaluate the role of two predictors of work and family outcomes thus far unexplored in the work-family literature: fathers' family and religious involvement at home. We adapt Voydanoff's [5] WorkFamily Interface framework to create a specific model (see Fig. 1) from which we generated our hypotheses. Using a highly religious sample of fathers who are members of The Church of Jesus Christ of Latter-day Saints (LDS), fathers who are highly involved in religious activities at home and family life are compared to fathers who are less involved. Crossover effects between work and family are also examined.

\section{THEORETICAL FRAMEWORK AND EMPIRICAL REVIEW}

The conceptual framework for this study draws from three different theories. The framework is largely based in ecological systems theory [6] and Voydanoff's [5] specific application of this framework to the work-family interface. Ecological systems theory posits that the work microsystem and family microsystem interact and reciprocally influence one another through permeable boundaries and, together, comprise the work-family mesosystem.

The framework proposes that there are work and family adaptive strategies that may influence the relationship

*Address correspondence to this author at the School of Family Life, 2052 JFSB, Brigham Young University, Provo, UT 84602, USA; Tel: 801-4220379; Fax: 801-422-0230; E-mail: jeff_hill@byu.edu between work and family characteristics, work-family conflict, work-family fit, and work and family outcomes [5].

Spillover theory [7] is also used in our framework. Spillover refers to the influence, either positive or negative, that work and family microsystems can have on each other. This comes from the assumptions that individuals have finite resources and that expending these resources in one domain (such as work) diminishes the resources available for other domains (such as family) [8]. However, spillover can be moderated by factors such as flexible work arrangements. For example, when individuals have access to job flexibility, they are able to better meet their work and family demands, leading to positive outcomes for both work and family [9].

Sanctification theory also contributes to our framework. Sanctification is the process of imbuing a worldly concern with spiritual significance [3]. Religious men may consider their family relationships and work to be spiritually significant because such behaviors are seen as a divinely appointed responsibility to care for their families [10].

Because some of the variables and relationships examined in this study have not been explored by previous research, our hypotheses are guided by the theoretical perspectives we have identified as well as related research. For example, research has explored the impact of fathers' family and religious involvement on child development and marital relations. Research on these topics and others will be reviewed to enhance the rational for our study.

\section{FATHERS' FAMILY AND RELIGIOUS INVOLVE- MENT AND FAMILY OUTCOMES}

Paternal investment is related to a range of positive child outcomes including educational attainment, economic achievement, emotional well-being, and social competence [1]. This influence occurs through fathers' contributions to their children's attachment and social capital, among other potential pathways [11].

The most specific conceptual model frequently used to evaluate father involvement in the fatherhood literature [12, 


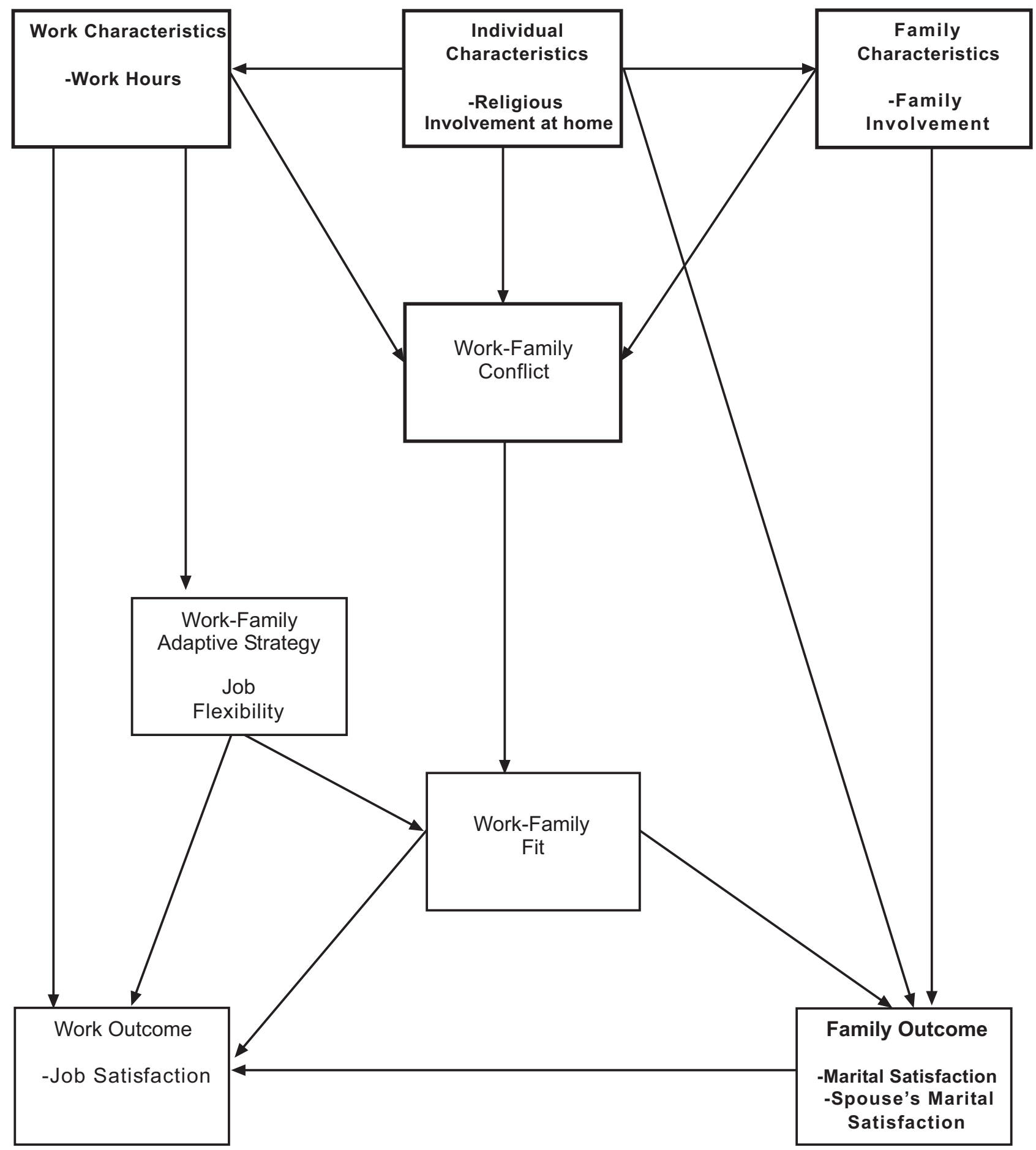

Fig. (1). Conceptual model of fathers' religious involvement and family involvement at home and work and marital outcomes (emphasis added to unique variables in this study).

13] encompasses motivation, skills and self-confidence, social supports and stresses, and institutional structures, but excludes religion. Although a recently developed conceptual model of father involvement recognizes religion as a contextual factor that can affect father involvement [4], religion has not received much attention in research on father involvement. Yet, Wilcox [10] found that paternal religiosity is a critical consideration in promoting father involvement (spe- cifically, one-on-one activities, dinner time, and youth activities). Furthermore, these effects existed even when controlling for fathers' conventionality, which was also related to father involvement.

A recent study of religious fathers found that "religion provided a powerful and unique worldview and framework of fathering that inspired and guided their actual beliefs and 
behaviors as fathers" [14]. Other studies support this conclusion showing that highly religious fathers are more involved and affectionate with their children than fathers who are less religious or non-religious $[15,16]$.

This connection between religious fathers' spiritual beliefs and father behavior can be explained by sanctification, in which "aspects of life are perceived by people as having a spiritual character and significance" [3]. Religious fathers may attribute "sacred qualities" to the act of providing for and interacting with their families because their family relationships are attributed with "ultimate value and purpose" [3]. Latshaw [17] found that for highly religious fathers, being involved with their children was considered a natural extension of the sacred center of meaning and identity provided by their faith, making it nearly inconceivable that they would be an "uninvolved father" (p. 68).

Although various religions emphasize the family to different degrees [18], many religions place high emphasis on family relationships [10] and outline specific behaviors key to fathers' roles [19]. Thus, the relationship between religiosity and father behavior can also be explained through role theory; religions provide various expectations for father behavior that highly religious individuals are motivated to meet in order to solidify their role identity [19]. However, it should be noted that even non-religious individuals may consider their family relationships and duties to be key to their identities as well as sacred; sanctification does not require association with a theistic being [3].

Religious men may also sanctify their marital relationships. Highly religious men are more likely to socialize with their wives and show higher levels of emotional attentiveness than less religious or non-religious men; in turn, their wives are more likely to report happiness with the love and affection and the appreciation for housework they receive from their husbands [16]. Such associations suggest that when fathers are more religious, their marital quality is likely to be higher.

\section{WORK INVOLVEMENT, WORK-FAMILY INTER- FACE, AND WORK AND FAMILY OUTCOMES}

Participating in paid employment is an important economic contribution fathers make to their families [11]. Yet, research on the work-family interface demonstrates that some work and family factors are associated with negative outcomes for families and the workplace. For example, longer work hours are consistently associated with increased work-family conflict, "a form of interrole conflict in which the role pressures from the work and family domains are mutually incompatible in some respect" [20]. Work-family conflict, in turn, negatively predicts work outcomes such as job satisfaction and organizational commitment [21] and family outcomes such as poor role performance and family dissatisfaction [22].

Matthews et al. [23] found that work-family conflict increases when work demands distract employees from their family responsibilities. More recent research has shown that professionals who spent more time and involvement with their families than with their work had less work-family conflict than those who spent equal amounts of time and involvement in both work and family domains [24]. These families experienced a higher level of "work-family fit, " which is defined as the overall perception of how successfully paid work and family life are integrated.

The concept of work-family fit suggests that although the potential for work-family conflict can be high, demanding roles can support and energize one another rather than cause overload and dysfunction [25]. Work-family fit can be facilitated through flexible work options, which can increase individuals' abilities to manage work and family demands [9]. In fact, job flexibility has been associated with many beneficial family outcomes, such as increased involvement and decreased work-family conflict [26] as well as numerous work outcomes, such as job satisfaction, employee morale, and workplace performance [27] and organizational commitment and decreased turnover [28].

The psychological distress resulting from increased work-family conflict has also been associated with decreased marital satisfaction [29], increased relationship hostility, and decreased warmth and supportiveness [30] in the marital relationship. Matthews et al. [23] found that work-family conflict from either spouse's job was related to their partners experiencing psychological distress/suffering. They concluded that "conflict from a spouse's job causes as much distress as conflict from one's own job" (p. 73). Other studies have found a bidirectional effect, finding that marital satisfaction predicts positive work outcomes [31, 32]. Because theory and research support the mutual influence of work and family domains, it is reasonable to explore whether fathers' family and religious involvement also affects work outcomes.

\section{HYPOTHESES}

The findings presented in this literature review suggest that fathers' family and religious involvement may facilitate important work and family outcomes. This study seeks to illuminate whether and how family and religious involvement at home influence work and family outcomes. The following hypotheses will be tested:

H1: Fathers with high religious involvement at home will report less work-family conflict and greater work-family fit than fathers with low religious involvement.

H2: Fathers with high religious involvement and their spouses will report greater marital satisfaction than fathers with low religious involvement and their spouses.

H3: Fathers with high religious involvement at home will report greater job satisfaction than fathers with low religious involvement.

H4: Fathers with high family involvement will report less work-family conflict and greater work-family fit than fathers with low family involvement.

H5: Fathers with high family involvement and their spouses will report greater marital satisfaction than spouses of fathers with low family involvement and their spouses.

H6: Fathers with high family involvement will report greater job satisfaction than fathers with low family involvement.

H7: Fathers with high religious and family involvement will report less work-family conflict and greater work-family fit than fathers with low religious and family involvement. 
H8: Fathers with high religious and family involvement and their spouses will report greater marital satisfaction than fathers with low religious and family involvement and their spouses.

H9: Fathers with high religious and family involvement will report greater job satisfaction than fathers with low religious and family involvement.

\section{MATERIALS AND METHODOLOGY}

\section{Sample and Procedures}

The data for this study come from the 2001 Marriott School of Management Alumni Work and Family Survey. The Marriott School of Management is located at Brigham Young University in Provo, Utah. This survey provides descriptive data of the work, family, and religious beliefs and practices of participants. Approximately 750 males and 750 females were randomly selected from a stratified list of 9000 alumni and invited to participate. If married, their spouses were asked to complete the spouse questionnaire. The overall response rate of $40 \%$ resulted in 576 alumni surveys and 450 spouse surveys. This was higher response than the rate of return (30\%) typical of nationally mailed questionnaires [33] and considerably higher than the $23 \%$ response rate in a similar study of Wharton and Drexel business school alumni [34]. The sub-sample $(n=210)$ used for these analyses consisted of employed, married male respondents with at least one child. Each participant's spouse also completed a spouse survey. For further details, refer to Clarke et al. [25].

The unique characteristics of this sample limit generalizing these findings to the population at large but are ideal for the research questions of this study. All participants are members of The Church of Jesus Christ of Latter-day Saints. Latter-day Saints are known for their high commitment to both family and religion, key variables in this study. Further, the alumni tend to be employed within a wide range of businesses and organizations [25], representing a diverse workforce of business professionals [34].

The mean age of respondents was 38 years (mean age of spouses was 36 years). Overall, respondents had personal incomes that were higher than the national average (about $\$ 82,000)$, were in their first marriages $(97 \%)$, and were employed in supervisory positions (68\%). Average job tenure was approximately 4.5 years. Respondents also had more children than the national average (about 4.2). Sixty-two percent of the sample had at least one preschooler, $60 \%$ had at least one school-aged child and $42 \%$ of the sample had at least one teenager. Eighty-four percent had at least one child between the ages of zero and 12 years old.

\section{Measures}

The independent variables evaluated in this study were religious involvement, family involvement, work hours, and in some analyses work-family conflict, job flexibility, and work-family fit. The dependent variables include workfamily conflict, work-family fit, job satisfaction, and selfand spouse-reports of marital satisfaction.

Religious involvement. Fathers' religious involvement at home was assessed with a three-item scale summing the number of days per week (0-7) respondents prayed with their children, prayed with their families, and read scriptures with their families. The range of possible scores was $0-21$. The range of scores was then divided into nearly equal tertiles in order to compare individuals with relatively higher and lower religious activity. Thirty-seven percent of respondents were in the high range (score $17-21), 31 \%$ were in the medium range (14-16), and $31 \%$ were in the low range (0-13). Although these activities may not be perfect proxies for commitment to religion, because such activities are private and typically unmonitored, they can represent observable expressions of inward faith [18].

Family involvement. This variable was assessed with an eight-item scale summing the number of days per week (0-7) respondents engaged in the following with one or more children: reading, working on family chores, helping with school work, preparing for bed, preparing dinner, doing something fun (e.g., playing a game) watching television, and eating dinner. The range of possible scores was 0 to 56 . The range of scores was divided into tertiles to compare individuals with relatively higher and lower family involvement. Fortythree percent of respondents were in the high range (31-56), $33 \%$ were in the medium range (22-30), and $23 \%$ were in the low range (0-21).

Work hours. A single, open-ended item was used to obtain an estimate of the number of hours worked per week for the last three months (including regularly scheduled work, overtime, work from home, etc.). Full-time employed fathers averaged 49 hours per week, and part-time employed fathers averaged 21 hours.

Job flexibility. Job flexibility was assessed with a fiveitem scale. For two items, respondents rated their level of flexibility ( $1=$ no flexibility, $5=$ complete flexibility) in selecting where and when they worked in order to evaluate two key domains of work flexibility, "flexplace" and "flextime" [35]. For three additional items, respondents rated their level of agreement ( 1 = strongly disagree, $4=$ strongly agree $)$ with the statements, "Working from home at least one day per week is acceptable in my work group"; "It is easy for me to arrive late or leave early to attend to family or personal commitments"; and "It is easy for me to take time off during the day to attend to family or personal commitments." Cronbach's alpha was .79.

Work-family conflict. Work-family conflict was assessed with four items in which respondents rated how often $(1=$ rarely, $4=$ most of the time) their jobs had interfered with their marital relationships (e.g., "Because of my job, I didn't have the energy to do things with my spouse/partner") or their relationships with their children (e.g., "Because of my job, I didn't have the energy to do things with my children"). Cronbach's alpha was .88.

Work-family fit. Work-family fit was assessed with one item to which respondents rated the ease $(1=$ very difficult, 4 $=$ very easy) with which they managed work and personal/family demands.

Job satisfaction. Job satisfaction was assessed with four items in which respondents rated their agreement $(1=$ strongly disagree, 4 = strongly agree) with statements such as the following, "Compared to other organizations I know about, my organization is the best place to work, " and "Considering everything, I am satisfied with my job." Cronbach's alpha was .87 . 
Marital satisfaction. The six items used to assess marital satisfaction were selected from a sixteen-item scale of marital satisfaction using exploratory factor analysis. Respondents were asked to rate their satisfaction $(1=$ very dissatisfied, $5=$ very satisfied) with the following aspects of their marital satisfaction: love experienced, conflict resolution, communication quality, respect for one another, willingness to forgive, and overall relationship. Cronbach's alpha was 93. The same items were used to assess spouses' marital satisfaction. Cronbach's alpha was .92.

\section{Analysis}

The data were analyzed by comparing means and utilizing corresponding ANOVAs. Ordinary Least Squares regression was performed to assess the strength of the relationships among variables. Regression analyses examined interactions between fathers' religious and family involvement. Regression was also used to determine whether marital satisfaction predicted job satisfaction.

\section{RESULTS}

\section{Correlations}

Correlations, means and standard deviations can be found in Table 1. In general, correlations revealed that fathers' religious and family involvement were positively related. Religious and family involvement were also both positively related to self- and spouse-reports of marital satisfaction and negatively related to work hours and work-family conflict. Work hours were positively related to work-family conflict and negatively related to work-family fit.

\section{Comparison of Means}

Means of each variable were generated along with corresponding one-way ANOVAs (see Tables 2-4). Because all of the hypotheses are directional in nature, we used $p<.05$ (one-tailed test) as the threshold for determining statistical significance. Effect sizes $(E S)$, which are calculated by dividing the difference between the two means by the average of the standard deviations of the two means [36], are also presented. Effect sizes of .2 are small, .5 are medium, and .8 are large [37].

H1: Fathers with high religious involvement will report less work-family conflict and greater work-family fit than fathers with low religious involvement. As shown in Table 2, fathers with high religious involvement did not report significantly less work-family conflict than fathers with low religious involvement $(\mathrm{ES}=-.44, \mathrm{~ns})$, although the difference was in the expected direction and of reasonable magnitude. Also, these fathers did not report significantly greater work-family fit than fathers with low religious involvement $(\mathrm{ES}=.07, \mathrm{~ns})$, although the difference was in the expected direction.

H2: Fathers with high religious involvement and their spouses will report greater marital satisfaction than fathers with low religious involvement and their spouses. As shown in Table 2, fathers with high religious involvement reported greater marital satisfaction $(\mathrm{ES}=.53, \mathrm{p}<.01)$ than fathers with low religious involvement. There was also a trend of spouses of fathers with high religious involvement reporting greater marital satisfaction than spouses of fathers with low religious involvement $(\mathrm{ES}=.41, \mathrm{p}<.10)$.

H3: Fathers with high religious involvement will report greater job satisfaction than fathers with low religious involvement. As shown in Table 2, fathers with high religious involvement did not report significantly greater job satisfaction than fathers with low religious involvement $(E S=.03$, $\mathrm{ns})$.

H4: Fathers with high family involvement will report less work-family conflict and greater work-family fit than fathers with low family involvement. As shown in Table 3, fathers with high family involvement reported significantly less

Table 1. Fathers' Reports of Work and Family Characteristics, Work-Family Conflict, Work-Family Fit, Job Flexibility and Work and Family Outcomes: Correlations and Descriptive Statistics $(\mathbf{n}=\mathbf{2 1 0})$

\begin{tabular}{|c|c|c|c|c|c|c|c|c|c|}
\hline Variables & 1 & 2 & 3 & 4 & 5 & 6 & 7 & 8 & 9 \\
\hline 1. Religious Involvement & - & & & & & & & & \\
\hline 3. Work Hours & $-.147 *$ & $-.200 * *$ & - & & & & & & \\
\hline 4. Work-Family Conflict & $-.166^{*}$ & $-.218^{* *}$ & $.356^{* *}$ & - & & & & & \\
\hline 6. Work-Family Fit & .014 & .134 & $-.336^{* *}$ & .087 & $-.594 * *$ & - & & & \\
\hline 7. Job Satisfaction & .000 & .067 & .055 & $.226 * *$ & $-.269 * *$ & $.229 * *$ & - & & \\
\hline 8. Marital Satisfaction & $.222 * *$ & $.176^{*}$ & -.136 & .020 & $-.334 * *$ & $.254 * *$ & $.223 * *$ & - & \\
\hline 9. Spouse's Mar. Satisfaction & $.199 * *$ & $.210 * *$ & -.042 & -.059 & $-.156^{*}$ & .086 & .088 & $.653 * *$ & - \\
\hline$\alpha$ & & & & .88 & .79 & & .87 & .93 & .92 \\
\hline
\end{tabular}


work-family conflict $(\mathrm{ES}=-.70, \mathrm{p}<.01)$ and greater workfamily fit $(\mathrm{ES}=.44, \mathrm{p}<.05)$ than fathers with low family involvement.

Table 2. Comparison of Fathers in High Religious Involvement Group to Fathers in Low Religious Involvement Group on Work and Family Characteristics, Work-Family Conflict, Work-Family Fit, Job Flexibility and Work and Family Outcomes

\begin{tabular}{|l|c|c|c|c|c|c|}
\hline & \multicolumn{2}{|c|}{ High } & \multicolumn{2}{c|}{ Low } & \multirow{2}{*}{ F } & \multirow{2}{*}{ ES a } \\
\cline { 2 - 6 } & Mean & SD & Mean & SD & & \\
\hline \hline Religious Involvement & 19.37 & 1.46 & 8.30 & 4.04 & $359.12^{* * *}$ & 4.03 \\
\hline Family Involvement & 26.44 & 9.20 & 18.64 & 9.26 & $13.53 * * *$ & .85 \\
\hline Work Hours & 49.08 & 6.81 & 51.54 & 8.94 & 1.75 & -.31 \\
\hline Work-Family Conflict & 1.70 & .70 & 2.02 & .76 & 5.80 & -.44 \\
\hline Job Flexibility & 2.75 & .66 & 2.82 & .72 & .86 & -.10 \\
\hline Work-Family Fit & 2.53 & .74 & 2.48 & .72 & .46 & .07 \\
\hline Job Satisfaction & 3.27 & .60 & 3.25 & .60 & .45 & .03 \\
\hline Marital Satisfaction & 4.35 & .65 & 3.94 & .88 & $5.21 * *$ & .53 \\
\hline Spouse Mar. Satisfaction & 4.35 & .64 & 4.04 & .86 & 2.80 & .41 \\
\hline
\end{tabular}

Note. Fathers in High Group $n=78$; Fathers in Low Group $n=65$.

${ }^{\dagger} p<.1 ; * p<.05 ; * * p<.01 ; * * * p<.001$.

${ }^{\mathrm{a}} E S($ Effect Size $)=\underline{\mathrm{M}}_{2}-\mathrm{M}_{1}$

$$
-\frac{\mathrm{M}_{2}-\mathrm{M}_{1}}{\left(\mathrm{SD}_{1}+\mathrm{SD}_{2}\right)} / 2
$$

Table 3. Comparison of Fathers in High Family Involvement Group to Fathers in Low Family Involvement Group on Work and Family Characteristics, WorkFamily Conflict, Work-Family Fit, Job Flexibility and Work and Family Outcomes

\begin{tabular}{|l|c|c|c|c|c|c|}
\hline & \multicolumn{2}{|c|}{ High } & \multicolumn{2}{c|}{ Low } & \multirow{2}{*}{ F } & \multirow{2}{*}{ ES } \\
\cline { 2 - 6 } & Mean & SD & Mean & SD & & \\
\hline \hline Religious Involvement & 17.28 & 3.31 & 12.77 & 6.05 & $13.74 * * *$ & .71 \\
\hline Family Involvement & 36.26 & 4.06 & 14.68 & 4.91 & $457.72^{* * *}$ & 4.81 \\
\hline Work Hours & 47.19 & 6.30 & 51.83 & 8.4 & $6.15^{* *}$ & -.63 \\
\hline Work-Family Conflict & 1.51 & .45 & 1.94 & .78 & $5.45^{* *}$ & -.70 \\
\hline Job Flexibility & 2.74 & .64 & 2.76 & .69 & .03 & -.03 \\
\hline Work-Family Fit & 2.73 & .72 & 2.40 & .77 & $3.30 *$ & .44 \\
\hline Job Satisfaction & 3.30 & .55 & 3.21 & .65 & .30 & .15 \\
\hline Marital Satisfaction & 4.45 & .54 & 4.06 & .82 & $4.27 *$ & .57 \\
\hline Spouse Mar. Satisfaction & 4.45 & .54 & 4.08 & .70 & $4.06 *$ & .60 \\
\hline
\end{tabular}

Note. Fathers in High Group $n=46$; Fathers in Low Group $n=90$.

$* p<.05 ; * * p<.01 ; * * * p<.001$.

${ }^{\mathrm{a}} E S($ Effect Size $)=\underline{\mathrm{M}}_{2}-\mathrm{M}_{1}$

$$
\left(\mathrm{SD}_{1}+\mathrm{SD}_{2}\right) / 2
$$

H5: Fathers with high family involvement and their spouses will report greater marital satisfaction than spouses of fathers with low family involvement and their spouses. As shown in Table $\mathbf{3}$, fathers with high family involvement re- ported significantly greater marital satisfaction than fathers with low family involvement $(\mathrm{ES}=.57, \mathrm{p}<.05)$, and their spouses reported significantly greater marital satisfaction than spouses of fathers with low family involvement (ES = $.60, \mathrm{p}<.05)$.

H6: Fathers with high family involvement will report greater job satisfaction than fathers with low family involvement. As shown in Table 3, fathers with high family involvement did not report significantly greater job satisfaction than fathers with low family involvement $(E S=.15$, ns), although the difference was in the expected direction.

H7: Fathers with high religious and family involvement will report less work-family conflict and greater work-family fit than fathers with low religious and family involvement. As shown in Table 4, fathers with high religious and family involvement reported significantly less work-family conflict than fathers with low religious and family involvement (ES $=-.94, p<.01)$. However, these fathers did not report significantly greater work-family fit than fathers with low religious and family involvement $(\mathrm{ES}=.42$, ns), although the effect size was in the expected direction.

Table 4. Comparison of Fathers in High Religious/High Family Involvement Group to Fathers in Low Religious/ Low Family Involvement Group on Work and Family Characteristics, Work-Family Conflict, WorkFamily Fit, Job Flexibility and Work and Family

\begin{tabular}{|c|c|c|c|c|c|c|}
\hline & \multicolumn{2}{|c|}{ High-High } & \multicolumn{2}{|c|}{ Low- Low } & \multirow{2}{*}{$\boldsymbol{F}$} & \multirow{2}{*}{$E S^{\text {a }}$} \\
\hline & Mean & $S D$ & Mean & $S D$ & & \\
\hline Religious Involvement & 19.44 & 1.64 & 7.18 & 4.48 & $118.67 * * *$ & 4.01 \\
\hline Family Involvement & 36.21 & 3.67 & 12.93 & 5.75 & $100.94 * * *$ & 4.94 \\
\hline Work Hours & 46.83 & 6.14 & 52.74 & 8.68 & $4.90 * *$ & -.80 \\
\hline Work-Family Conflict & 1.49 & .48 & 2.07 & .76 & $6.15^{* *}$ & -.94 \\
\hline Job Flexibility & 2.81 & .68 & 2.90 & .72 & 1.76 & -.13 \\
\hline Work-Family Fit & 2.75 & .70 & 2.45 & .72 & 1.37 & .42 \\
\hline \multicolumn{7}{|l|}{$W$ and $F$ Outcomes } \\
\hline Job Satisfaction & 3.27 & .53 & 3.18 & .63 & .26 & .16 \\
\hline Marital Satisfaction & 4.48 & .56 & 4.02 & .80 & $3.17 *$ & .68 \\
\hline Spouse Mar. Satisfaction & 4.57 & .49 & 4.11 & .71 & $3.60 *$ & .77 \\
\hline \multicolumn{7}{|c|}{$\begin{array}{l}\text { Note. Fathers in High-High Group } n=29 \text {; Fathers in Low-Low Group } n=39 \text {. } \\
* p<.05 ; * * p<.01 ; * * *<<.001 .\end{array}$} \\
\hline
\end{tabular}
Outcomes

H8: Fathers with high religious and family involvement and their spouses will report greater marital satisfaction than fathers with low religious and family involvement and their spouses. As shown in Table 4, fathers with high religious and family involvement reported significantly greater marital satisfaction than fathers with low religious and family involvement $(\mathrm{ES}=.68, \mathrm{p}<.05)$, and spouses of these fathers reported significantly greater marital satisfaction than spouses of fathers with low religious and family involvement $(\mathrm{ES}=.77, \mathrm{p}<.05)$. 
H9: Fathers with high religious and family involvement will report greater job satisfaction than fathers with low religious and family involvement. As shown in Table 4, fathers with high religious and family involvement did not report significantly greater job satisfaction than fathers with low religious and family involvement $(\mathrm{ES}=.16$, ns), although the difference was in the expected direction.

\section{Multiple Regression Analysis}

We conducted a series of multivariate analyses to further explore the variables of interest. Religious involvement, family involvement, work hours and, in some regressions, work-family conflict, job flexibility, work-family fit, and marital satisfaction were independent variables. Work-family conflict, work-family fit, job satisfaction, and self- and spouse-reports of marital satisfaction were dependent variables. We would have liked to use a model that assessed the degree of fit of the data with the conceptual model (i.e., structural equation modeling), but this technique was not attempted due to small sample size.

Work-family conflict. Work hours positively predicted work-family conflict $(\beta=.322, p<.001)$. There was a statistical trend for family involvement was negatively predicting work-family conflict $(\beta=-.132, p<.1)$. However, religious involvement was not significantly associated with workfamily conflict. The R-squared for this regression model was .133 .

Work-family fit. Work hours $(\beta=-.130, p<.05)$, religious involvement $(\beta=-.104, p<.10)$ and work-family conflict $(\beta=-.571, p<.001)$ were all negatively associated with work-family fit. However, family involvement and job flexibility were not significantly associated with work-family fit. The R-squared for this regression model was .373.

Job satisfaction. Two regression models were constructed with job satisfaction as the dependent variable: one without marital satisfaction and one with marital satisfaction. In step one, work hours $(\beta=.179, p<.05)$ and job flexibility $(\beta=.141, p<.05)$ were positively associated with job satisfaction, work-family conflict was negatively associated with job satisfaction $(\beta=.223, p<.05)$, and religious involvement, family involvement and work-family fit were not significantly associated with job satisfaction. The R-squared for this regression model was .111.

In step two, work hours $(\beta=.182, p<.05)$ and job flexibility $(\beta=.141, p<.05)$ positively predicted job satisfaction, and there was a trend of marital satisfaction positively predicting job satisfaction $(\beta=.136, p<.1)$. Work-family conflict $(\beta=-.203, p<.05)$ negatively predicted job satisfaction. Religious involvement, family involvement and workfamily fit did not significantly predict job satisfaction. The $\mathrm{R}$-squared for this regression model was .117.

Marital satisfaction. Religious involvement positively predicted marital satisfaction $(\beta=.180, p<.05)$. Workfamily conflict negatively predicted marital satisfaction $(\beta=$ $-.249, p<.01)$. The variables of work hours, family involvement and work-family fit did not significantly predict marital satisfaction. The R-squared associated with this regression model was .141. No significant associations were found between spouse's marital satisfaction and work hours, religious involvement, family involvement, work-family conflict, job flexibility or work-family fit. The R-squared for this regression model was .038.

\section{Interactions}

We next conducted analyses to determine whether the religious and family involvement variables interact. Standard deviations of \pm 2 were used to represent low and high levels of religious involvement. Prior to analysis, collinearity was detected among the variables, so we standardized the religious and family involvement variables and re-computed the interaction term. In these analyses, we controlled for work hours, religious involvement, family involvement, work-family con-

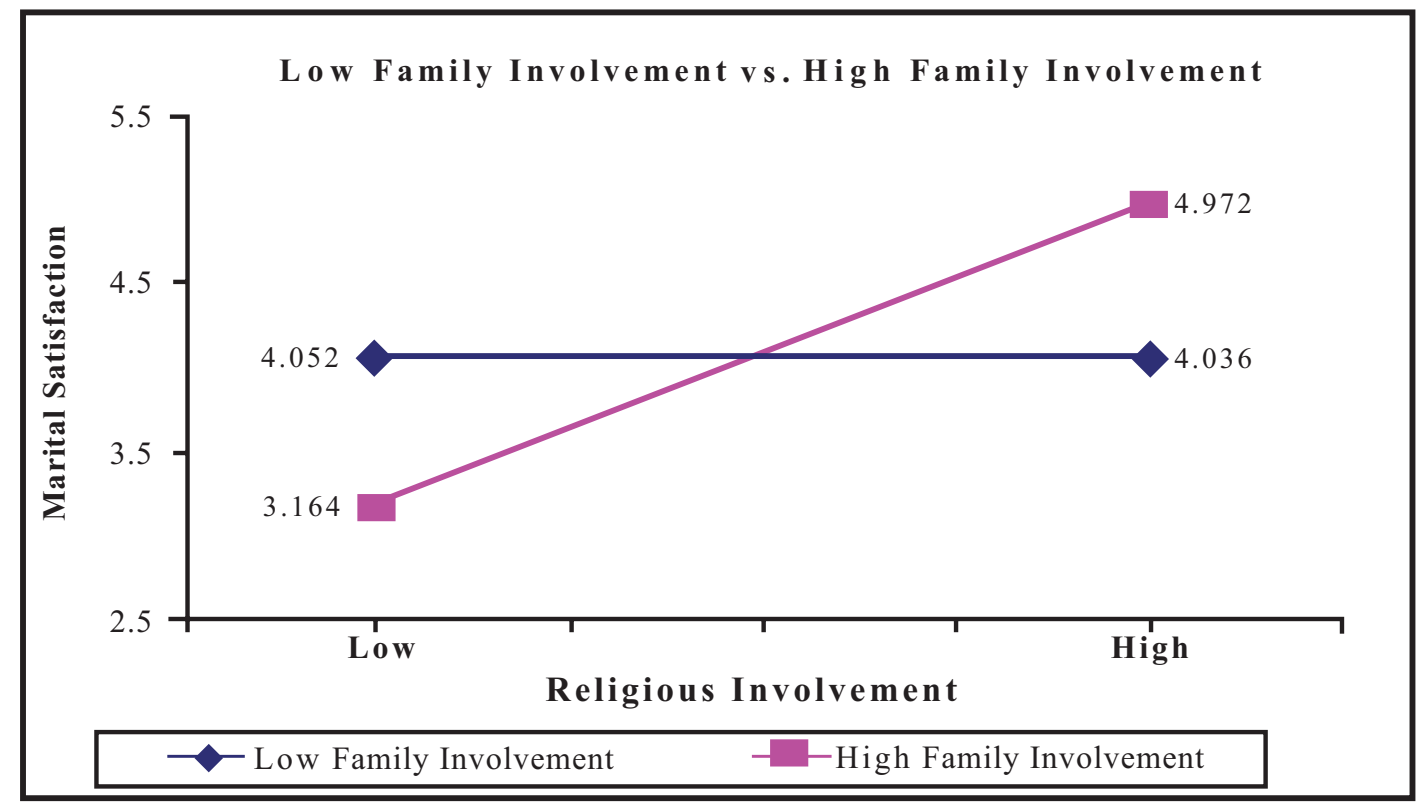

Fig. (2). Expected means of marital satisfaction controlling for Work Hours, Religious Involvement at Home, Family Involvement at Home, Work-Family Conflict, Job Flexibility, and Work-Family fit. 


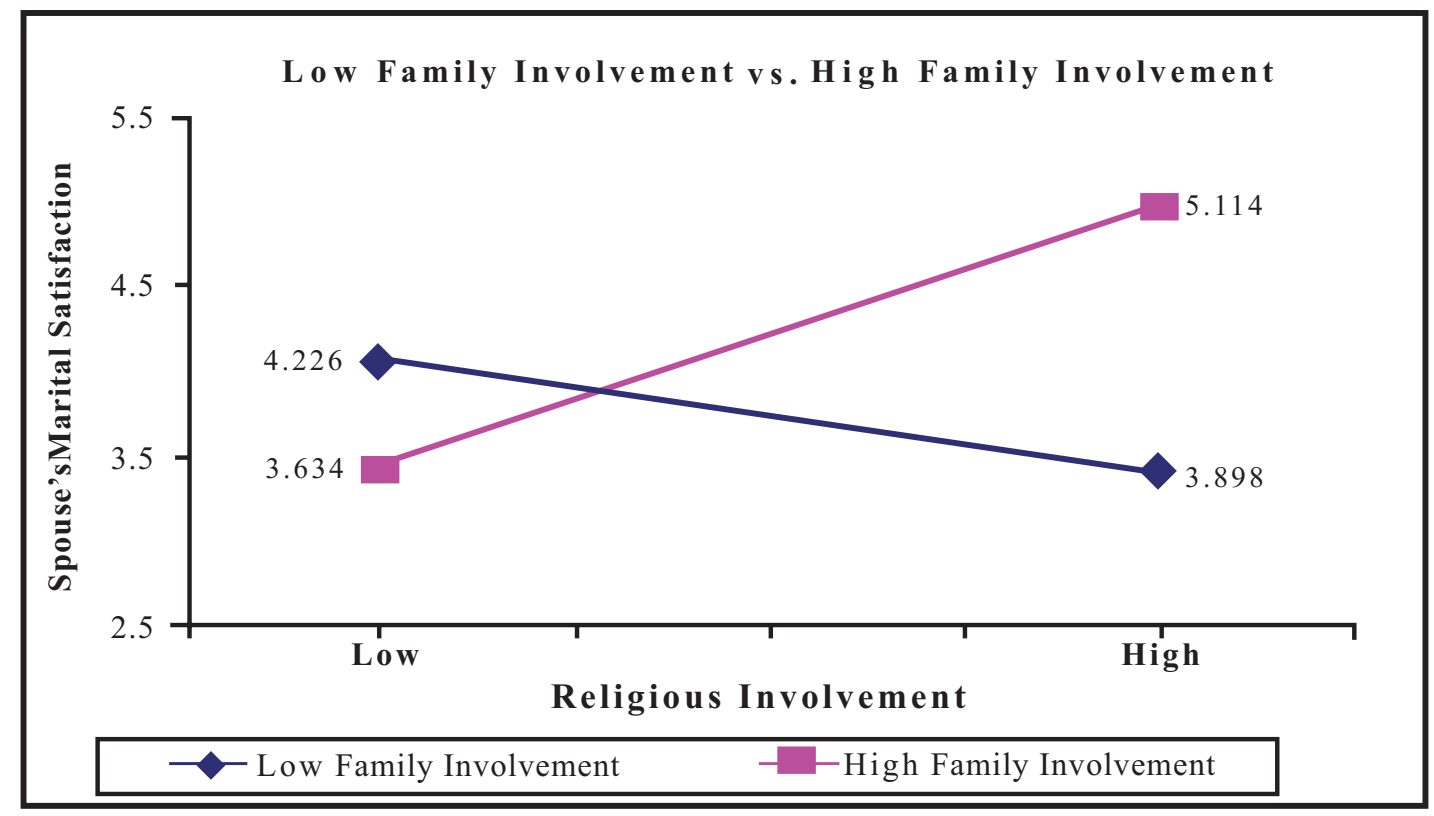

Fig. (3). Expected means of Spouses' Marital Satisfaction controlling for Work Hours, Religious Involvement at Home, Family Involvement at Home, Work-Family Conflict, Job Flexibility, and Work-Family Fit.

flict, job flexibility, and work-family fit. Two trends were found for the expected means of self- $(p<.10)$ and spousereports $(p<.10)$ of marital satisfaction (see Figs. 2 and 3).

For fathers with low family involvement, the relationship between religious involvement and marital satisfaction was nearly undetectable, with only a slightly negative relationship between fathers' religious involvement and self-reports of marital satisfaction. For fathers with low family involvement, expected means for marital satisfaction decreased slightly from 4.052 for fathers with low religious involvement to 4.036 for fathers with high religious involvement. However, for fathers with high family involvement, there was a strong positive relationship between religious involvement and marital satisfaction. For fathers with high family involvement, expected means for marital satisfaction increased from 3.164 for fathers with low religious involvement to 4.972 for fathers with high religious involvement.

For spouses of fathers with low family involvement, a negative relationship existed between fathers' religious involvement and marital satisfaction. That is, when fathers were more religiously involved, their spouses' marital satisfaction was lower. Expected means of marital satisfaction for spouses of fathers in the low family involvement group decreased from 4.226 for spouses of fathers with low religious involvement to 3.898 for fathers with high religious involvement. However, as predicted, for spouses of fathers with high family involvement there was a strong positive relationship between the fathers' religious involvement and spouses' marital satisfaction. Expected means of spouses' marital satisfaction for fathers with high family involvement dramatically increased from 3.634 for spouses of fathers with low religious involvement to 5.114 for fathers with high religious involvement.

\section{DISCUSSION}

This study investigates two new predictors of work and family outcomes: fathers' religious and family involvement.
By examining a sample of Latter-day Saints (LDS) who hold graduate degrees, this study offers a unique look at work and family outcomes for fathers who value religion and family.

\section{Family and Religious Involvement Crossover Effects}

This study revealed significant crossover between the domains of work and family for fathers. Although this was not found for fathers with high religious involvement, fathers with high family involvement reported significantly less work-family conflict and greater work-family fit than fathers with low family involvement. This is an important finding because past research has found work-family conflict and work-family fit to be related to a number of important work and family outcomes such as job loyalty [38] and employee health [39].

While fathers' family or religious involvement did not predict their job satisfaction (these relationships may have emerged as significant with a larger sample), this study did find that fathers with high religious involvement and their spouses reported greater marital satisfaction than fathers with low religious involvement and their spouses. This is an important finding because marital satisfaction contributes to father involvement [40] and positive parenting behavior [41], both of which are relevant to child well-being [1]. Sanctification theory [3] provides a possible explanation for this effect of religious involvement on marital satisfaction. A father who views his family relationships as sacred will naturally feel greater marital satisfaction from investing more time and effort in religious involvement. Family involvement also had a significant positive effect on both self- and spouse-reports of marital satisfaction. This could be explained by Lamb's [42] suggestion that fathers who provide emotional support to their wives and children feel a greater sense of role fulfillment.

Furthermore, there was a statistical trend of fathers' marital satisfaction predicting job satisfaction. This finding replicates past research establishing a relationship between the 
marital and work domains [31, 32]. Given the existence of this relationship, there are implications for employers seeking to avoid the high costs associated with employee turnover which often results when employees are not satisfied with their jobs [43]. Employers could facilitate greater job satisfaction through the use of flexible work arrangements that may allow fathers more time with their families. This recommendation receives further support from our finding that job flexibility contributes to the prediction of job satisfaction.

\section{High Religious and Family Involvement Enhances Family Outcomes}

In this study we examined the effects of fathers' family and religious involvement together on the dependent variables of interest. Examined separately, fathers' religious involvement and family involvement were only modest predictors of marital satisfaction. But the interaction of fathers' religious and family involvement produced more powerful predictions of self- and spouse-reports of marital satisfaction.

For fathers with low family involvement, there was not a significant relationship between their religious involvement at home and marital satisfaction. Thus, fathers who are relatively uninvolved with their families do not experience enhanced marital satisfaction simply as a result of religious involvement with family members. However, fathers with high family involvement report higher marital satisfaction when they have higher levels of religious involvement at home. This relationship also exists with spouses' marital satisfaction. This finding supports recent scholarship that suggests high religious involvement magnifies the positive effects of high family involvement [16, 15]

\section{Limitations and Suggestions for Future Research}

There are some important limitations to this study. The sample differs from national samples in a number of important ways. First, there was an unusually high response rate to the survey from which data was drawn. However, it may be that this response rate was higher than other similar surveys (e.g., [34]) due to the unique nature of the sample. The sample consists of highly religious individuals who graduated from an institution sponsored by their religion. These individuals may have felt more of an obligation or interest in responding to the survey because of their continued religious affiliation with the sponsoring institution. The sample also was above the national average on income, education, and career achievement, among other variables. Many of the respondents may hold managerial or executive positions that provide greater access to job flexibility than lower-income jobs. Yet, it is these unique characteristics of the sample that allow for the analyses conducted in this study.

Furthermore, although this sample does not yield findings that are generalizable to most populations, it is not appropriate to ignore this population. As expressed by Dollahite et al. [18], "highly religious families [and highly educated and employed fathers, we might add] are themselves a diverse type of family" and deserve attention. While this research may not apply to most types of families, it can still contribute to our understanding of the role of religion in family and work life and lead to more creative and critical thinking about such relationships.
Some of the variables in this study may also create limitations. The single-item measure chosen for work-family fit was selected for its high face-validity. While it would be ideal to combine more items to latently assess work-family fit, this measure was limited by the existing data set. Also, the latent variable of family involvement included seven items, three of which related to younger children. It was determined that the variable was an adequate measure for this sample, however, given that $84 \%$ of the sample had at least one child under twelve years old. Another issue is that the measure of religious involvement used in this study could be seen as a special type of family involvement, potentially confounding some of the results. It may be more appropriate for future research to use more distinct measures of religious and family involvement.

Future research should test this model by applying it to a larger sample of Latter-day Saint fathers, as well as highly religious fathers from other religious groups. Also, comparisons of highly religious working mothers and fathers would illuminate whether mothers and fathers harmonize work and family obligations differently. Finally, using structural equation modeling may provide more accurate prediction of the relationships between variables within the model.

\section{CONCLUSIONS}

Responsible fathering and its resulting effects on the well-being of families and children has become a central source of societal concern. Yet, the work-family issues working fathers face have received little attention from researchers. This study introduces two new predictors of work and family outcomes: fathers' religious and family involvement. Overall, this study provides support for the relationship between fathers' religious and family involvement and valued work and family outcomes such as work-family conflict, work-family fit, and marital satisfaction. While there are some limitations to the generalizability of these findings, this study provides illuminating information on the relationships between some previously unanalyzed work and family domains and suggests the need for continued research in this area.

\section{ACKNOWLEDGEMENTS}

We thank the Family Studies Center of the BYU School of Family Life for its support of our work. Special thanks to research assistants Jeremy Boyle, Natasha Davis, Rachel Loser, Nicole Mead, and Hannah Hill who aided in the preparation of this manuscript.

\section{REFERENCES}

[1] Flouri E. Fathering and child outcomes. West Sussex: John Wiley and Sons 2005

[2] Hill EJ, Baker RZ, Hawkins AJ, Märtinson V, Ferris, M. Working fathers: The forgotten half of working parents. Paper presented at the BPW From 9-to-5 to 24/7: How Workplace Changes Impact Families Work, and Communities Conference, Orlando, FL 2003.

[3] Mahoney A, Pargament KI, Murray-Swank A, Murray-Swank N. Religion and the sanctification of family relationships. Rev Relig Res 2003; 44: 220-36.

[4] Cabrera N, Fitzgerald HE, Bradley RH, Roggman L. Modeling the dynamics of paternal influences on children over the life course. Appl Dev Sci 2007; 11: 185-9.

[5] Voydanoff P. Linkages between the work-family interface and work, family, and individual outcomes: An integrative model. J Fam Issues 2002; 23: 138-64. 
[6] Bronfenbrenner U. Ecology of the family as a context for human development: Research perspectives. Dev Psychol 1986; 22: 72342.

[7] Zedeck S. Work, families, and organizations. San Francisco: Jossey-Bass Publishers 1992.

[8] Frone MR. Work-family balance. In: Quick JC, Tetrick LE, Eds. Handbook of occupational health psychology. Washington, DC: American Psychological Association 2003; pp. 143-62.

[9] Voydanoff P. Work, Family, and Community: Exploring Interconnections. Mahwah (NJ): Lawrence Erlbaum Associates 2007.

[10] Wilcox WB. Religion, convention, and paternal involvement. J Marriage Fam 2002; 64: 780-92.

[11] Pleck JH. Why could father involvement benefit children? Theoretical perspectives. Appl Dev Sci 2007; 11: 196-202.

[12] Doherty WJ, Kouneski EF, Erikson MF. Responsible Fathering: An overview and conceptual framework. J Marriage Fam 1998; 60: 277-92.

[13] Lamb ME. Introduction: The emergent American father. In: Lamb $\mathrm{ME}, \mathrm{Ed}$. The father's role: Cross-cultural perspectives. Hillsdale (NJ): Lawrence Erlbaum Associates 1987; pp. 3-25.

[14] Dollahite DC. Fathering for eternity: Generative spirituality in Latter-day Saint fathers of children with special needs. Rev Relig Res 2003; 44: 339-51

[15] Bartkowski JP, Xu X. Distant patriarchs or expressive dads? The discourse and practice of fathering in conservative Protestant families. Sociol Q 2000; 41: 465-85.

[16] Wilcox WB. Soft patriarchs, new men: How Christianity shapes fathers and husbands. Chicago (IL): University of Chicago Press 2004.

[17] Latshaw JS. The centrality of faith in fathers' role construction: The faithful father and the Axis Mundi paradigm. J Men's Stud 1998; 7: 53-70.

[18] Dollahite DC, Marks LD, Goodman MA. Families and religious beliefs, practices, and communities: Linkages in a diverse and dynamic cultural context. In: Coleman M, Ganong LH, Eds. Handbook of contemporary families: Considering the past, contemplating the future. Thousand Oaks (CA) 2004; pp. 411-31.

[19] Chatters LM, Taylor RJ. Religion and families. In: Bengtson VL, Acock AC, Allen KR, Dilworth-Anderson P, Klein DM, Eds. Sourcebook of family theory and research. Thousand Oaks, CA: Sage 2005; pp. 517-22.

[20] Greenhaus JH, Beutell NJ. Sources of conflict between work and family roles. Acad Manage Rev 1985; 10(1): 76-88.

[21] Lu L, Kao S, Chang T, Wu H, Cooper C. Work/family demands, work flexibility, work/family conflict, and their consequences at work: A national probability sample in Taiwan. Int J Stress Manag 2008; 15: 1-21.

[22] Voydanoff P. Work-to-family conflict and facilitation. J Marriage Fam 2004; 66: 398-412.

[23] Matthews LS, Conger RD, Wickrama KA. Work-family conflict and marital quality: Mediating processes. Soc Psychol Q 1996; 59: 62-79.

[24] Greenhaus JH, Collins KM, Shaw JD. The relation between workfamily balance and quality of life. J Vocat Behav 2003; 63: 510-31.
[25] Clarke MC, Koch LC, Hill EJ. The work-family interface, Differentiating balance and fit. Fam Consum Sci Res J 2004; 33(2): 12140.

[26] Meyer JA. Examining workplace flexibility across work and family domains. Dissertation Abstracts International: Section B. Sci Eng 1997; 57(8-B): 5375.

[27] Stavrou ET. Flexible work bundles and organizational competitiveness: A cross national study of the European work context. J Organ Behav 2005; 26: 923-47.

[28] Glass J, Finley A. Coverage and effectiveness of family-responsive workplace policies. Hum Resour Manage R 2002; 12(3): 313-37.

[29] Swanson V, Power KG. Stress, satisfaction and role conflict in dual-doctor partnerships. Commun Work Fam 1999; 2(1): 67-88.

[30] Major VS, Klein KJ, Ehrhart MG. Work time, work interface with family, and psychological distress. J Appl Psychol 2002; 87: 427 36.

[31] Rogers SJ, May DC. Spillover between marital quality and job satisfaction: Long-term patterns and gender differences. J Marriage Fam 2003; 65: 482-95.

[32] Mauno S, Kinnunen U. The effects of job stressors on marital satisfaction in Finnish dual-earner couples. J Organ Behav 1999; 20 : 879-95.

[33] Christensen M. An interdisciplinary theoretical framework for the mailed questionnaire process and the development of a theory on immediacy and salience as significant variables of response rates (Doctoral dissertation, Utah State University, 1996). Dissertation Abstracts International: Section B. Sci Eng 1997; 57(7-B): 4779.

[34] Friedman SD, Greenhaus JH. Work and family-Allies or enemies? What happens when business professionals confront life choices. New York: Oxford University Press 2000.

[35] Hill EJ, Hawkins AJ, Ferris M, Weitzman M. Finding an extra day a week: The positive influence of perceived job flexibility on work and family life balance. Fam Relat 2001; 50(1): 49-58.

[36] Shaver JP. Handbook of research on social studies. New York: Macmillan Publishing Company 1991.

[37] Cohen J. Statistical power analysis for the behavioral sciences. Hillsdale (NJ): Lawrence Erlbaum 1988.

[38] Day AL, Chamberlain TC. Committing to your work, spouse, and children: Implications for work-family conflict. J Vocat Behav 2006; 68: 116-30.

[39] Grzywacz JG, Bass BL. Work, family, and mental health: Testing different models of work-family fit. J Marriage Fam 2003; 65(1): 248-62.

[40] Lee CS, Doherty WJ. Marital satisfaction and father involvement during the transition to parenthood. Fathering 2007; 5(2): 75-96.

[41] Krishnakumar A, Buehler C. Interparental conflict and parenting behaviors: A meta-analytic review. Fam Relat 2000; 49: 25-44.

[42] Lamb ME. Fatherhood Then and Now. In: Booth A, Crouter AC, Eds. Men in families: When do they get involved? What difference does it make? Mahwah (NJ): Lawrence Erlbaum Associates 1998; pp. 47-52.

[43] Hill EJ, Weiner S. Work/life balance policies and programs. In: Edwards JE, Scott JC, Raju NS, Eds. The human resources program-evaluation handbook. Newbury Park (CA): Sage 2003.

This is an open access article licensed under the terms of the Creative Commons Attribution Non-Commercial License (http://creativecommons.org/licenses/by$\mathrm{nc} / 3.0 /$ ) which permits unrestricted, non-commercial use, distribution and reproduction in any medium, provided the work is properly cited. 